\title{
Dendritic Growth, Eutectic Features and Their Effects on Hardness of a Ternary Sn-Zn-Cu Solder Alloy
}

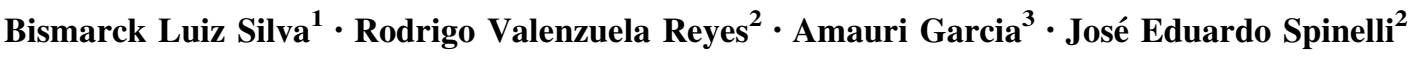

Received: 26 October 2016/Revised: 11 February 2017/Published online: 20 March 2017

(C) The Chinese Society for Metals and Springer-Verlag Berlin Heidelberg 2017

\begin{abstract}
The present investigation is based on the results of a directionally solidified (DS) $\mathrm{Sn}-9 \mathrm{wt} \% \mathrm{Zn}-2 \mathrm{wt} \% \mathrm{Cu}$ alloy, including primary/secondary/tertiary dendrite arm spacings of the Sn-rich matrix, the morphologies of the eutectic mixture and the corresponding interphase spacing, the nature and proportion of the $\mathrm{Cu}-\mathrm{Zn}$ intermetallic compound (IMC). The main purpose is to establish interrelations of these microstructure features with experimental solidification thermal parameters, such as cooling rates and growth rates $(v)$, macrosegregation and hardness. Such interrelations are interesting for both industry and academy since they represent a tool permitting the preprogramming of final properties based on the design of the microstructure. In the case of $\mathrm{Sn}-\mathrm{Zn}-\mathrm{Cu}$ alloys, hardly anything is known about the combined effects of the length scale of the microstructure and fraction and distribution of the primary IMC on hardness. The alloy microstructure is composed of a $\beta-\mathrm{Sn}$ dendritic region, surrounded by a eutectic mixture of $\alpha-\mathrm{Zn}$ and $\beta-\mathrm{Sn}$ phases and the $\gamma-\mathrm{Cu}_{5} \mathrm{Zn}_{8} \mathrm{IMC}_{\text {. }}$ The eutectic interphase spacing varies in the range $1.2-3.6 \mu \mathrm{m}$, with the $\alpha-\mathrm{Zn}$ phase having a globular morphology for $v>0.5 \mathrm{~mm} / \mathrm{s}$ and a needle-like morphology for $v<0.3 \mathrm{~mm} / \mathrm{s}$. A modified Hall-Petch-type experimental expression relating hardness to the interphase spacing is proposed.
\end{abstract}

KEY WORDS: Sn-Zn-Cu solder alloy; Solidification; Microstructure; Eutectic morphology; Hardness

\section{Introduction}

$\mathrm{Sn}-\mathrm{Zn}-\mathrm{Cu}$ alloys deserved attention in recent years due to their potential applications as lead-free solders, in kesteritebased solar cells, as negative electrodes in lithium-ion batteries and as corrosion-resistant layers potentially

Available online at http://link.springer.com/journal/40195.

José Eduardo Spinelli

spinelli@ufscar.br

1 Department of Materials Engineering, Federal University of Rio Grande do Norte-UFRN, Natal, RN 59078-970, Brazil

2 Department of Materials Engineering, Federal University of São Carlos - UFSCar, São Carlos, SP 13565-905, Brazil

3 Department of Manufacturing and Materials Engineering, University of Campinas, UNICAMP, Campinas, SP 13083-860, Brazil combining the features of brass and bronze [1]. The combination of these alloys with $\mathrm{S}$ or $\mathrm{Se}$ allows their use as layers in thin films (CZTS- $\mathrm{Cu}_{2} \mathrm{ZnSnS}_{4}$ and $\left.\mathrm{CZTSe}-\mathrm{Cu}_{2} \mathrm{ZnSnSe}_{4}\right)$. These materials may replace thin-film solar cells containing indium and gallium, which are more expensive [1].

Until recently, lead-based alloys have been extensively used as solders in electronic boards of the electronics industry. However, the new legislations worldwide have restricted the use of lead due to its negative impact on the human health and environment [2]. During the last decade, several Sn-based lead-free solder alloys with compositions varying according to the applications have been proposed. $\mathrm{Sn}-\mathrm{Ag}-\mathrm{Cu}$ [3, 4] and $\mathrm{Sn}-\mathrm{Zn}$ [5] alloys are considered among the most attractive substitutes for the traditional leaded solders. Sn-Zn alloys are well known for their good mechanical properties, low melting points and relatively low cost. The addition of third and fourth elements to $\mathrm{Sn}-$ $\mathrm{Zn}$ alloys has been attempted to improve their reliability 
during the soldering process. According to the literature, the addition of $\mathrm{Cu}$ can improve the corrosion resistance [6] and wettability $[7,8]$ and minimize the dezincification during corrosion [9]. The comprehension of the wetting behavior of these alloys becomes an essential task since wetting of binary $\mathrm{Sn}-\mathrm{Zn}$ solders on $\mathrm{Cu}$ substrates is recognized as very poor [10]. Non-wetting areas and voids can be seen frequently on the solder/substrate interface. Three reaction layers are typically reported in this case, which are formed by $\mathrm{Cu}_{5} \mathrm{Sn}_{8}$ adjacent to the solder, a middle layer of $\mathrm{Cu}_{5} \mathrm{Zn}_{8}$ and a Cu-rich layer of CuZn. The addition of $\mathrm{Na}$ to $\mathrm{Sn}-\mathrm{Zn}$ solders causes not only a decrease in the thickness of the layer formed by intermetallics at the interface between the solder alloy and the $\mathrm{Cu}$ substrate, but also a minor increase in the spreading area when compared with the non-modified alloy [11].

Lin and Shih [12] reported that microadditions of silver $(\mathrm{Ag}<0.5 \%)$ to the eutectic $\mathrm{Sn}-9 \mathrm{wt} \% \mathrm{Zn}$ solder alloy may affect the whole alloy microstructure, which is finally characterized by the competitive growth of $\mathrm{Ag}_{5} \mathrm{Zn}_{8}$ and $\mathrm{AgZn}_{3}$ intermetallic particles with the eutectic phase. Another investigation related to Ag-containing $\mathrm{Sn}-9 \mathrm{Zn}$ alloys [13] reported that the addition of $1.5 \mathrm{wt} \% \mathrm{Ag}$ may induce acceptable tensile properties, i.e., the ductility is improved while preserving the tensile strength. In this case, higher cooling rates are reported to cause finer microstructures, producing better tensile properties.

According to the literature [5, 14], two different morphologies can be assumed by the $\alpha$-Zn phase during transient directional solidification at different growth rates $(v)$ : globular and needle like. For a eutectic Sn-9 wt $\% \mathrm{Zn}$ solder alloy, globular $\alpha-Z n$ particles have been associated with $v>0.5 \mathrm{~mm} \mathrm{~s}^{-1}$ and needle-like particles predominated for $v<0.3 \mathrm{~mm} \mathrm{~s}^{-1}$ [14]. However, information correlating solidification thermal parameters of ternary $\mathrm{Sn}-\mathrm{Zn}-\mathrm{Cu}$ alloys, such as the cooling rate, to the resulting microstructural morphologies cannot be found in the literature. El-Daly and Hammad [15] investigated the microstructural aspects of a $\mathrm{Sn}-9 \mathrm{Zn}-0.7 \mathrm{Cu}$ solder alloy and reported that the microstructure was formed by a $\beta-\mathrm{Sn}$ matrix, Zn-rich phases and small dark-gray rod-shaped intermetallic compounds (IMCs) $\left(\mathrm{Cu}_{6} \mathrm{Sn}_{5}, \mathrm{Cu}_{5} \mathrm{Zn}_{8}\right.$ and $\mathrm{CuZn}_{5}$ ). This investigation has also demonstrated that the $\alpha$-Zn phase, grown in the Cu-modified alloy, tended to be finer than that observed in the binary $\mathrm{Sn}-9 \mathrm{Zn}$ alloy. In agreement with that, Rahman and collaborators [16] concluded that when $\mathrm{Cu}$ is added to the $\mathrm{Sn}-9 \mathrm{Zn}$ eutectic alloy, the length scale of the $\alpha-Z n$ phase decreases. Studies performed by Lee et al. and Liu et al. [17, 18] have shown that with the increase in $\mathrm{Cu}$ alloying, the volume fraction of IMCs increases while that of the $\alpha$-Zn phase of the eutectic mixture decreases.
It is known that the dendritic/eutectic microstructures of solder alloys may be affected by the cooling rate experienced during liquid-to-solid transformation of a solder fillet [19-23]. The alloy mechanical strength is a consequence of microstructural characteristics. The effects of cooling rate and growth rate on the formation and evolution of the microstructure of the $\mathrm{Sn}-\mathrm{Zn}-\mathrm{Cu}$ alloys have not been completely investigated so far. The characterization of dendritic and eutectic microstructural arrangements (scale, morphology and distribution of phases) in solder alloys is considered an essential task since these microstructure features are very common in solder fillets.

A comparison between the tensile properties of $\mathrm{Sn}-9 \mathrm{Zn}$ and $\mathrm{Sn}-9 \mathrm{Zn}-0.7 \mathrm{Cu}$ alloys is shown in a study performed by El-Daly and Hammad [15]. The ultimate tensile strength (UTS) and elongation to failure of the as-solidified $\mathrm{Sn}-9 \mathrm{Zn}$ eutectic alloy and of the $\mathrm{Sn}-9 \mathrm{Zn}-0.7 \mathrm{Cu}$ alloy were reported to be 52 and $58 \mathrm{MPa}$ and $22 \%$ and $32 \%$, respectively. In the case of $\mathrm{Sn}-9 \mathrm{Zn}$ alloys modified with $\mathrm{Cu}$ additions, Lee et al. [17] observed that the elongation is similar to that of the Sn-9Zn eutectic alloy (around 30\%) up to the addition of $2 \mathrm{wt} \% \mathrm{Cu}$. When $4 \mathrm{wt} \% \mathrm{Cu}$ was added, the elongation decreased abruptly from $31 \%$ (Sn-9Zn alloy) to $19 \%$ for the $\mathrm{Sn}-9 \mathrm{Zn}-4 \mathrm{Cu}$ alloy. Furthermore, UTS values of about $50 \mathrm{MPa}$ were obtained and remained roughly unaffected by the $\mathrm{Cu}$ content for all $\mathrm{Sn}-9 \mathrm{Zn}-(x \mathrm{Cu})$ ternary alloys evaluated for a $\mathrm{Cu}$ content up to $4 \mathrm{wt} \%$. Therefore, the evolution of mechanical properties with $\mathrm{Cu}$ content in ternary $\mathrm{Sn}-9 \mathrm{Zn}-x \mathrm{Cu}$ alloys is a topic deserving more research attention.

Rahman et al. [16] determined the hardness evolution of ternary $\mathrm{Sn}-9 \mathrm{Zn}-x \mathrm{Cu}$ alloys as a function of their $\mathrm{Cu}$ content. The hardness of a eutectic $\mathrm{Sn}-9 \mathrm{Zn}$ alloy was found to be $16.8 \mathrm{HV}$, while those of $\mathrm{Sn}-9 \mathrm{Zn}-0.4 \mathrm{Cu}, \mathrm{Sn}-9 \mathrm{Zn}-0.7 \mathrm{Cu}$ and $\mathrm{Sn}-9 \mathrm{Zn}-1.0 \mathrm{Cu}$ alloys were $21,16.6$ and $15.5 \mathrm{HV}$, respectively. The $\mathrm{Sn}-9 \mathrm{Zn}$ eutectic alloy has been reported to be formed by two phases: the $\beta$-Sn matrix and small amounts of needle-like $\alpha-Z n$ in the eutectic mixture, with some $\alpha-Z n$ spheroids in it. The presence of $Z n$-rich spheroids in the microstructure of the $\mathrm{Sn}-9 \mathrm{Zn}$ eutectic alloy can hinder the movement of dislocations enhancing the mechanical strength [14]. Further, it has been found that the hardness firstly increases with the addition of 0.4 wt\% $\mathrm{Cu}$ to the $\mathrm{Sn}-9 \mathrm{Zn}$ alloy, but decreases for larger $\mathrm{Cu}$ additions (0.7 and $1.0 \mathrm{wt} \%)$. The resulting lower hardness values obtained for the ternary $\mathrm{Sn}-9 \mathrm{Zn}-0.7 \mathrm{Cu}$ and $\mathrm{Sn}-$ $9 \mathrm{Zn}-1.0 \mathrm{Cu}$ alloys have been attributed to the presence of smaller amounts of the $\alpha-Z n$ phase in the eutectic mixture due to the existence of large IMCs particles precipitated in the $\beta$-Sn matrix, which consume more $\mathrm{Zn}$ from the original bulk solder. Thus, less $\mathrm{Zn}$ would be available for the eutectic reaction. 


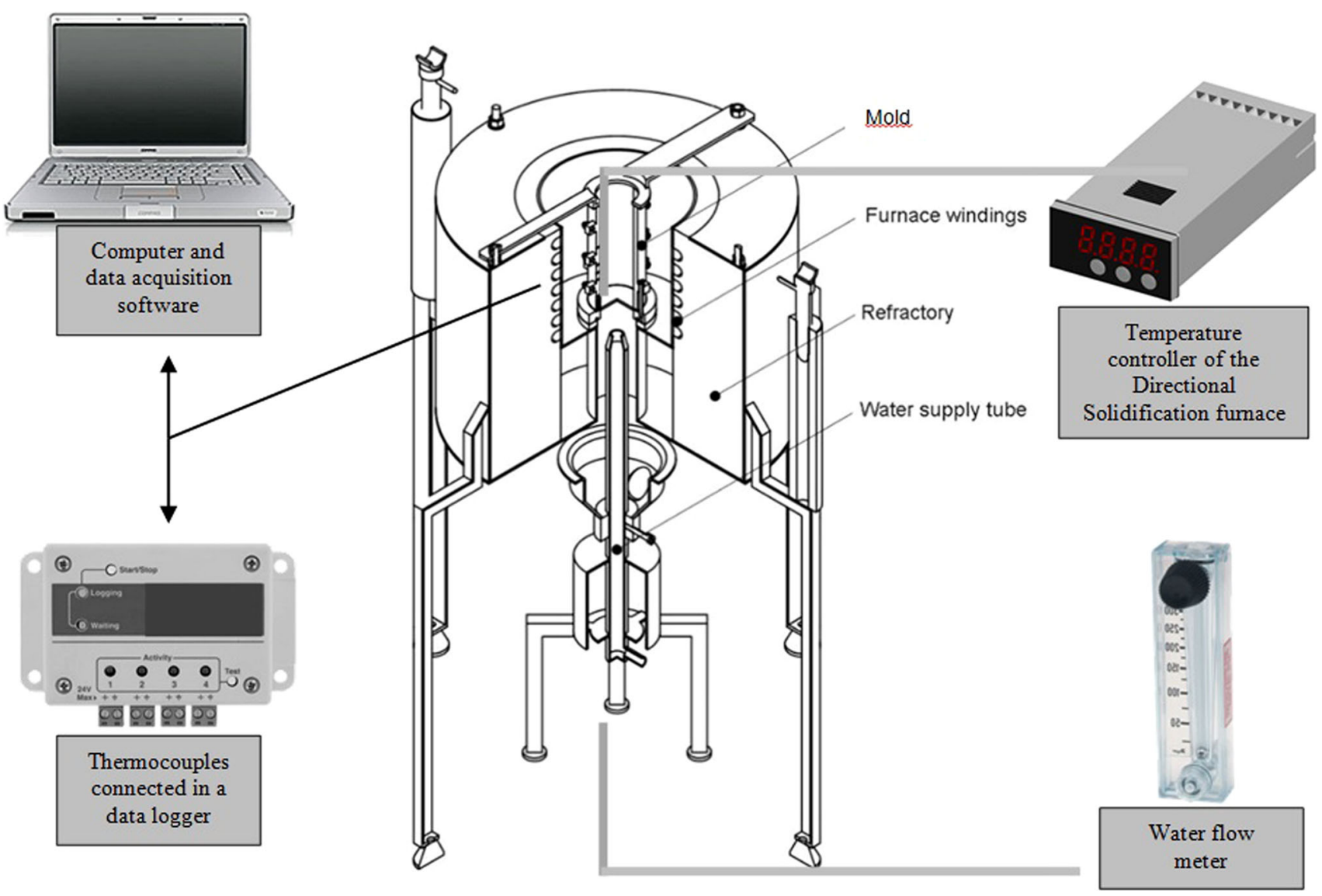

Fig. 1 Vertical upward directional solidification casting assembly and its devices

$\mathrm{Sn}-9 \mathrm{Zn}-x \mathrm{Cu}(x=1,2$, and $4 \mathrm{wt} \%)$ ternary alloys were subjected to thermal analysis by using differential scanning calorimetry (DSC) [17]. The DSC results have been combined with thermodynamic data provided by the CALPHAD software (Pandat and Thermo Calc) with a solder database (ADAMIS). The resulting solidification sequence concerning equilibrium conditions for the $\mathrm{Sn}-9 \mathrm{wt} \% \mathrm{Zn}-$ $2 \mathrm{wt} \% \mathrm{Cu}$ alloy has been reported to be represented as follows: $\mathrm{L} \rightarrow\left(\mathrm{L}+\gamma-\mathrm{Cu}_{5} \mathrm{Zn}_{8}\right) \rightarrow\left(\mathrm{L}+\gamma-\mathrm{Cu}_{5} \mathrm{Zn}_{8}+\varepsilon-\right.$ $\left.\mathrm{CuZn} \mathrm{Z}_{5}+\beta-\mathrm{Sn}\right) \rightarrow\left(\gamma-\mathrm{Cu}_{5} \mathrm{Zn}_{8}+\varepsilon-\mathrm{CuZn}_{5}+\beta-\mathrm{Sn}+\mathrm{eu}-\right.$ tectic $\beta-\mathrm{Sn} / \alpha-\mathrm{Zn})$ phases. However, there is a lack of investigations in the literature regarding the formation and the evolution of the microstructure $\mathrm{Sn}-\mathrm{Zn}-\mathrm{Cu}$ solder alloys for non-equilibrium cooling conditions. The effects of the cooling rate and segregation on the volume fraction of phases, nature and distribution of intermetallics in $\mathrm{Sn}-\mathrm{Zn}-$ $\mathrm{Cu}$ alloys remain undetermined.

$\mathrm{Cu}$ is known to react with $\mathrm{Zn}$ in preference to $\mathrm{Sn}$, because of the greater reactivity of $\mathrm{Zn}$. In ternary alloy systems like $\mathrm{Sn}-\mathrm{Zn}-\mathrm{Cu}, \mathrm{Cu}-\mathrm{Sn}$, compounds are difficult to form until all the free $\mathrm{Zn}$ phase is consumed. However, Rahman et al. [16] reported the presence of two different $\mathrm{Cu}$-based IMCs having two different shapes, which were formed through reactions with both $\mathrm{Zn}$ and $\mathrm{Sn}$ during solidification of the $\mathrm{Sn}-9 \mathrm{Zn}-0.4-1.0 \mathrm{Cu}$ alloy. The identified IMCs were: rodshaped $\gamma-\mathrm{Cu}_{5} \mathrm{Zn}_{8}$ and flower-shaped $\mathrm{Cu}_{6} \mathrm{Sn}_{5}$.

In the present investigation, the microstructural spacings of both the dendritic matrix and the eutectic mixture and the cooling thermal parameters (growth rates and cooling rates) were determined with the aim of establishing the experimental growth laws. Complete SEM and optical microscopy analyses were carried out. Moreover, the effect of $\mathrm{Cu}$ on both the length scale of the microstructure and the morphology of the $\alpha$ - $\mathrm{Zn}$ phase in the eutectic mixture were examined. Finally, the interrelations of the local length scale of the microstructure (interphase spacing) along the length of the directionally solidified (DS) casting with hardness were envisaged.

The main purposes of the present study are, firstly, to investigate the microstructural evolution of the ternary Sn$9 \mathrm{wt} \% \mathrm{Zn}-2 \mathrm{wt} \% \mathrm{Cu}$ solder alloy solidified under transient heat flow regime, and, secondly, to determine the variation in hardness as a function of the local microstructure features. 


\section{Experimental}

In order to promote a vertical upward solidification, an apparatus, designed in such a way that heat is directionally extracted by the bottom of the casting (Fig. 1), was used. The imposed transient directional solidification results in a wide range of microstructures solidified at different cooling rates in a single casting experiment. The solidification setup used in the experiments allows a unidirectional extraction of heat through a water-cooled bottom made of low carbon steel (SAE 1020), promoting a vertical upward directional solidification. A stainless steel split mold having an internal diameter of $60 \mathrm{~mm}$, a height of $157 \mathrm{~mm}$ and a wall thickness of $5 \mathrm{~mm}$ was used. The lateral inner mold surface was covered with a layer of insulating aluminasilica ceramics to minimize radial heat losses. The bottom part of the mold was closed with a thin ( $3 \mathrm{~mm}$ thick) steel sheet. The upward solidification experiment was carried out with a Sn-9 wt $\% \mathrm{Zn}-2 \mathrm{wt} \% \mathrm{Cu}$ alloy. Continuous temperature measurements in the casting were monitored during solidification via the output of a bank of fine type $\mathbf{J}$ thermocouples sheathed in $1.5 \mathrm{~mm}$ outside diameter stainless steel tubes and positioned at different positions from the heat-extracting surface at the bottom of the DS casting. All thermocouples were connected by coaxial cables to a data logger interfaced with a computer, and the temperature data were acquired automatically.

A single solidification experiment was carried out in the present investigation. However, the reproducibility of the directional solidification apparatus used has been checked in advance. The results provided by three repeated experiments are given in Table 1. These experiments were run with an alloy having its transformation temperature quite close to that of the $\mathrm{Sn}-9 \mathrm{wt} \% \mathrm{Zn}-2 \mathrm{wt} \% \mathrm{Cu}$ solder. The obtained deviations related to the times of passage of the liquidus isotherm regarding these experiments can be considered quite small. In general, an average standard deviation of $0.9 \%$ was obtained.

Selected transverse (perpendicular to the growth direction) and longitudinal cross sections of samples of the DS alloy casting were polished (solution of alumina $1 \mu \mathrm{m}$ ) and etched with a solution of $2 \mathrm{~mL} \mathrm{HCl}, 10 \mathrm{~mL} \mathrm{FeCl}_{3}$ and $100 \mathrm{~mL} \mathrm{H}_{2} \mathrm{O}$ applied for $10-30 \mathrm{~s}$ to reveal the microstructures. The adopted relative positions in the DS casting were located at $5,10,15,20,30,40,50,70$ and $90 \mathrm{~mm}$ from the cooled surface of the casting. An optical image processing system Olympus, GX51 (Olympus Co., Japan) was used to acquire the images. The primary,

Table 1 Results associated with the time $(t)$ of passage of the liquidus isotherm by distinct thermocouples positioned along the length of the DS casting for three identical directional solidification experiments

\begin{tabular}{|c|c|c|c|c|c|}
\hline $\begin{array}{l}\text { Position from the metal/mold } \\
\text { interface }(\mathrm{mm})\end{array}$ & $t_{1}(\mathrm{~s})$ & $t_{2}(\mathrm{~s})$ & $t_{3}(\mathrm{~s})$ & $\begin{array}{l}\text { Average time of passage } \\
\text { of liquidus isotherm (s) }\end{array}$ & $\begin{array}{l}\text { Standard } \\
\text { deviation }(\%)\end{array}$ \\
\hline 4.5 & 6 & 6 & 6 & 6.0 & 0.0 \\
\hline 9.5 & 13 & 14 & 13 & 13.3 & 0.4 \\
\hline 14.5 & 24 & 26 & 25 & 25.0 & 0.7 \\
\hline 18.5 & 36 & 37 & 37 & 36.7 & 0.4 \\
\hline 30.0 & 61 & 63 & 62 & 62.0 & 0.7 \\
\hline 43.0 & 112 & 116 & 114 & 114.0 & 1.3 \\
\hline 58.0 & 166 & 173 & 169 & 169.3 & 2.4 \\
\hline Average deviation & & & & & 0.9 \\
\hline
\end{tabular}
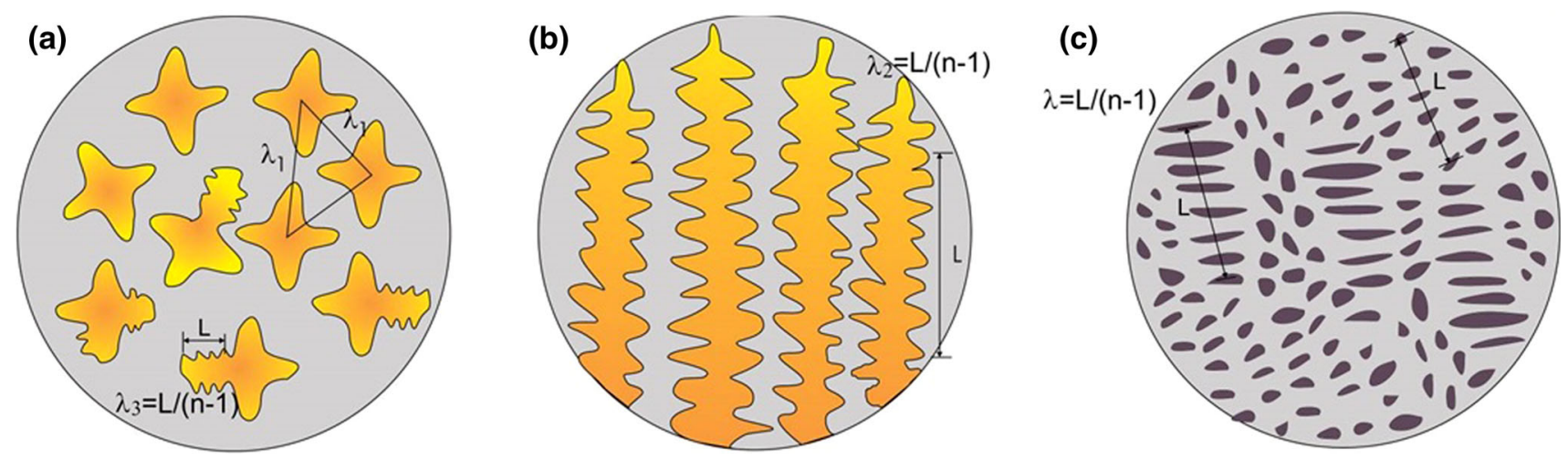

Fig. 2 Schematic representation of a, $\mathbf{c}$ transverse, $\mathbf{b}$ longitudinal sections with methods used to measure dendritic and interphase spacings: intercept method for $\lambda, \lambda_{2}$ and $\lambda_{3}$ and triangle method for $\lambda_{1}$ 

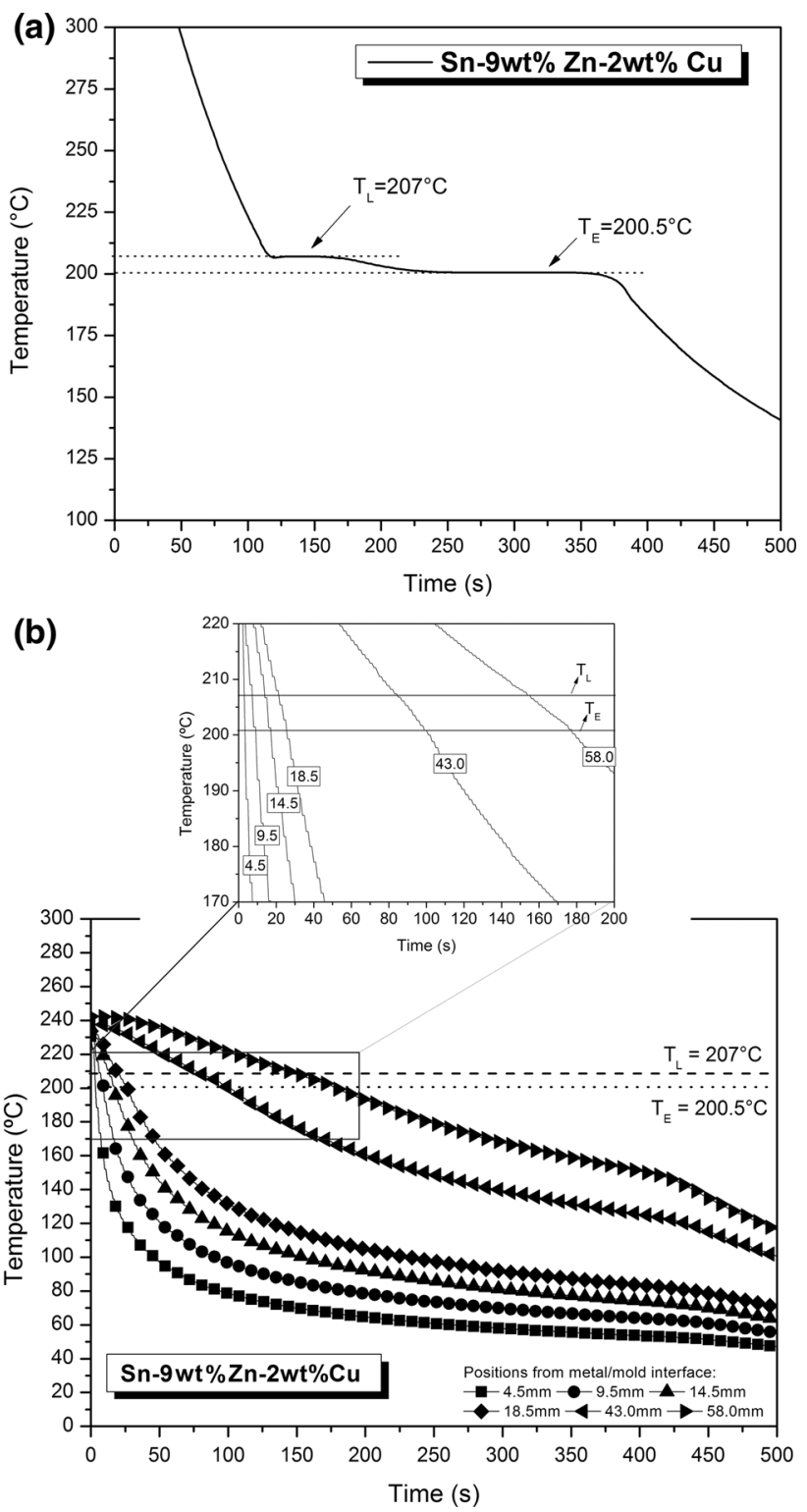

Fig. 3 a Experimental time-temperature curve allowing transformation temperatures to be determined; $\mathbf{b}$ experimental thermal profiles obtained along the length of the Sn-9 wt $\% \mathrm{Zn}-2 \mathrm{wt} \% \mathrm{Cu}$ alloy DS casting

tertiary $\left(\lambda_{1}, \lambda_{3}\right)$ and secondary $\left(\lambda_{2}\right)$ dendrite arm spacings $\left(\lambda_{2}\right)$ were measured on transverse and longitudinal sections of the DS casting, respectively. The triangle method was employed to measure $\lambda_{1}$, whereas $\lambda_{2}$ and $\lambda_{3}$ were measured by the intercept method, as reported by Gündüz and Çadirli [24] (see Fig. 2). The interphase spacings $(\lambda)$ were measured on the transverse sections by the intercept method as shown in Fig. 2c. At least 40 measurements were taken for each selected position along the length of the DS casting.

Furthermore, a more detailed microstructural characterization was performed by using a scanning electron microscope (SEM-EDS, FEI, Inspect S50L). Cross sections of samples of the ternary $\mathrm{Sn}-\mathrm{Zn}-\mathrm{Cu}$ alloy were examined by SEM, and elemental mapping was performed to determine the relative distribution of the elements.

Transverse samples were extracted from different positions along the length of the DS casting and investigated by a fluorescence spectrometer, model Shimadzu EDX-720, to estimate local average $\mathrm{Zn}$ and $\mathrm{Cu}$ concentrations. This permits to investigate the occurrence of long-range compositional differences (macrosegregation) along the length of the DS casting. The positions from the bottom of the casting selected for monitoring the macrosegregation of the casting were located at 5, 10, 15, 20, 30, 40, 50 and $70 \mathrm{~mm}$. The X-ray diffraction (XRD) patterns of the phases formed in the $\mathrm{Sn}-9 \mathrm{wt} \% \mathrm{Zn}-2 \mathrm{wt} \% \mathrm{Cu}$ alloy examined have been acquired by a Siemens D5000 diffractometer with a 2-theta range from $20^{\circ}$ to $90^{\circ}, \mathrm{CuK} \alpha$ radiation and a wavelength, $\lambda$, of $0.15,406 \mathrm{~nm}$. The XRD patterns were recorded at a scan speed of $2 \% \mathrm{~min}$. The XRD diffractograms were analyzed with the X'Pert HighScore Plus software, which enabled the reference codes to be assessed and the XRD peaks to be identified.

Hardness tests were performed on transverse sections of the samples by using a test load of $500 \mathrm{~g}$ and a dwell time of $15 \mathrm{~s}$. The adopted Vickers hardness was the average of at least 20 measurements on each sample. The positions selected for monitoring the hardness evolution were located at $5,10,15,20,25,30,40,50,60,70$ and $80 \mathrm{~mm}$ from the bottom of the casting. The area of indentation was large enough to encompass all microstructural phases, i.e., Snrich dendrites, eutectic mixture and IMCs.

\section{Results and Discussion}

The thermocouples inserted within the Sn-9 wt\%Zn$2 \mathrm{wt} \% \mathrm{Cu}$ alloy DS casting during solidification allowed to investigate the evolution of temperature $v s$ time along the length of the casting, as shown in Fig. 3b. Further, such experimental thermal profiles and the alloy liquidus temperature $\left(T_{\mathrm{L}}\right)$ of $207{ }^{\circ} \mathrm{C}$, measured by thermal analysis, have been used in order to determine the solidification cooling thermal parameters: growth rate $(v)$ and cooling rate $(\dot{T})$. Both liquidus and eutectic temperatures were determined in a previous experiment in which the alloy was slowly cooled in a well-insulated crucible, thus permitting the transformation temperatures to be determined, as shown in Fig. 3a. These temperatures are associated with the growth of the $\beta$ Sn dendrites, the primary $\mathrm{Cu}_{5} \mathrm{Zn}_{8}$ intermetallics and the eutectic mixture of $\alpha-\mathrm{Zn}$ and $\beta$-Sn [25].

The growth rates shown in Fig. $4 \mathrm{~b}$ were based on the time derivative of the fitting function representing a plot of 
(a)

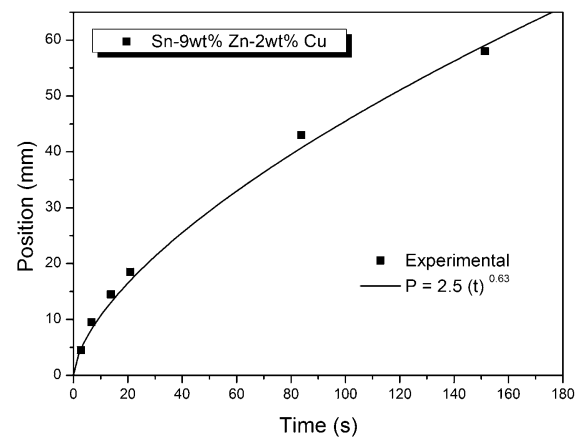

(b)

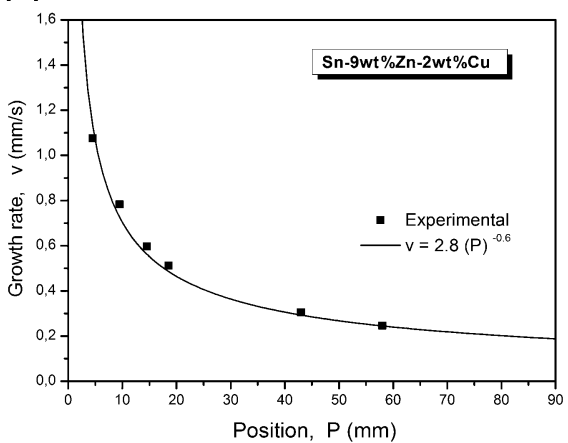

(c)

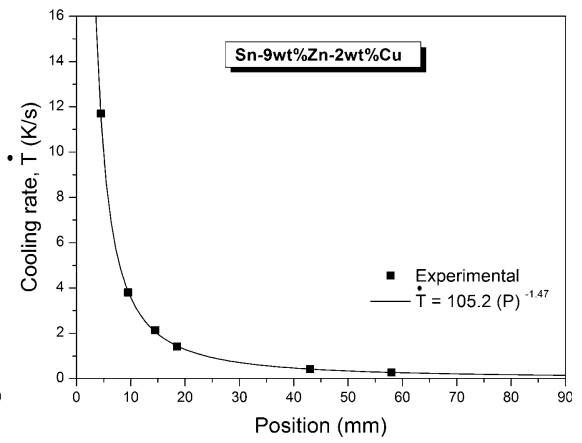

Fig. 4 Experimental profiles obtained for the $\mathrm{Sn}-\mathrm{Zn}-\mathrm{Cu}$ alloy corresponding to a position versus time taken by the liquidus front to reach each thermocouple; $\mathbf{b}$ growth rate, $\mathbf{c}$ cooling rate as a function of position

Longitudinal section
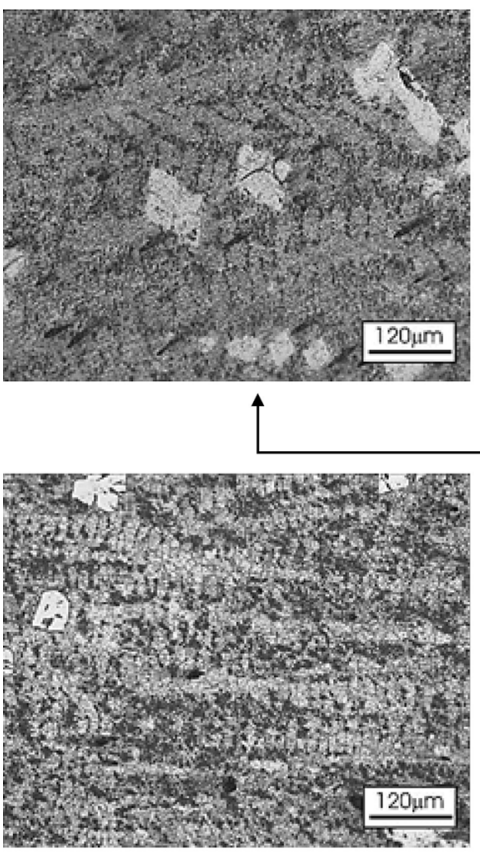

$\uparrow$
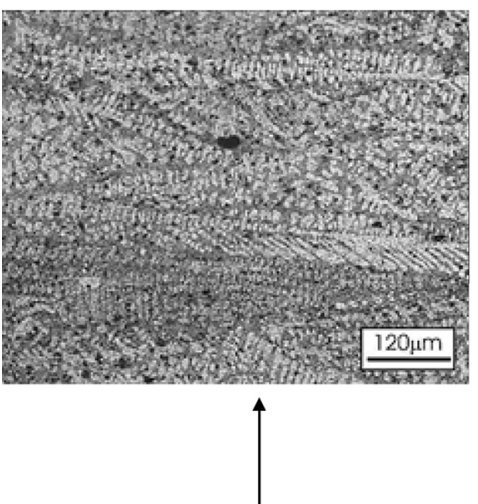

Macrostructure
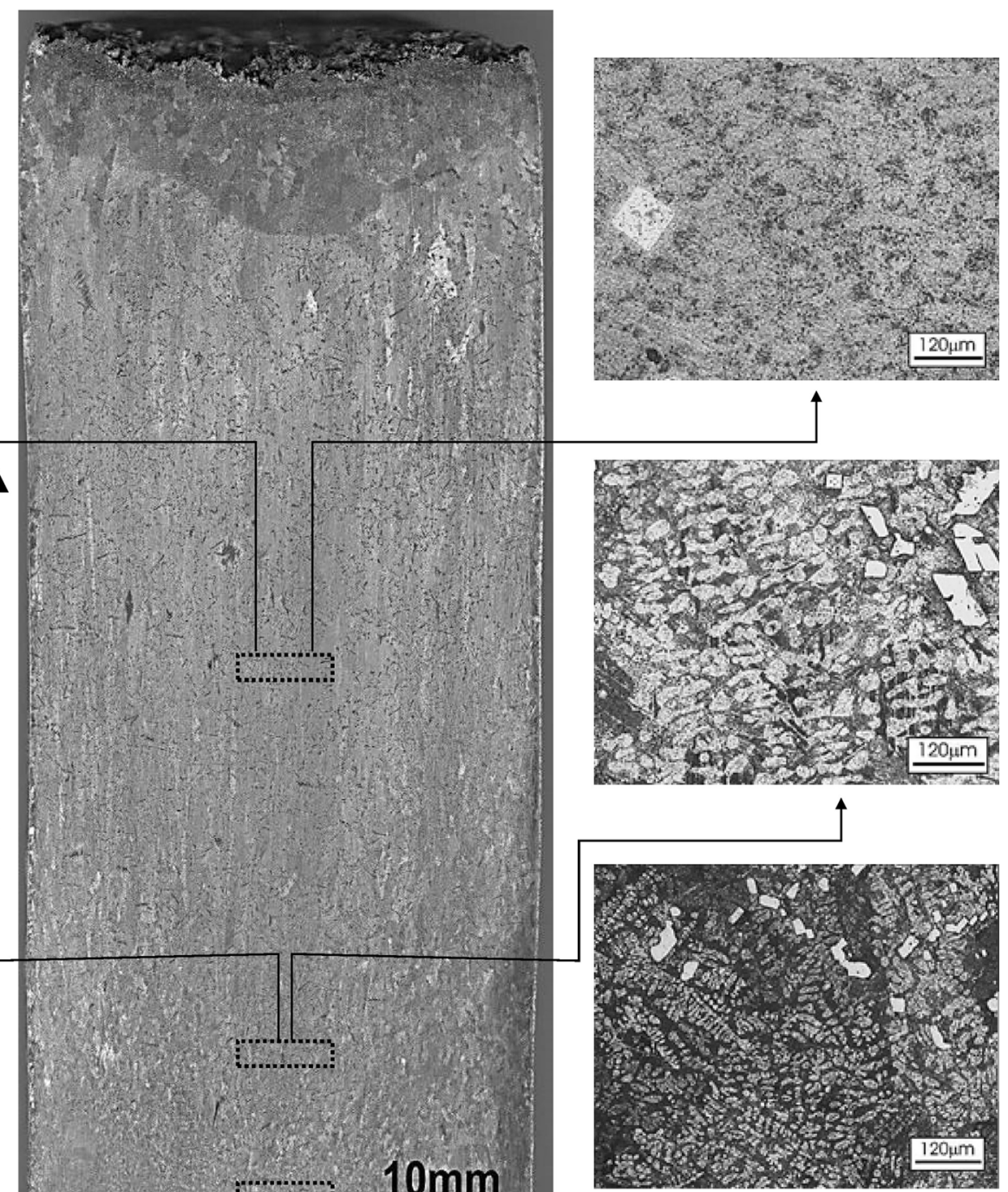

$10 \mathrm{~mm}$

Transverse section
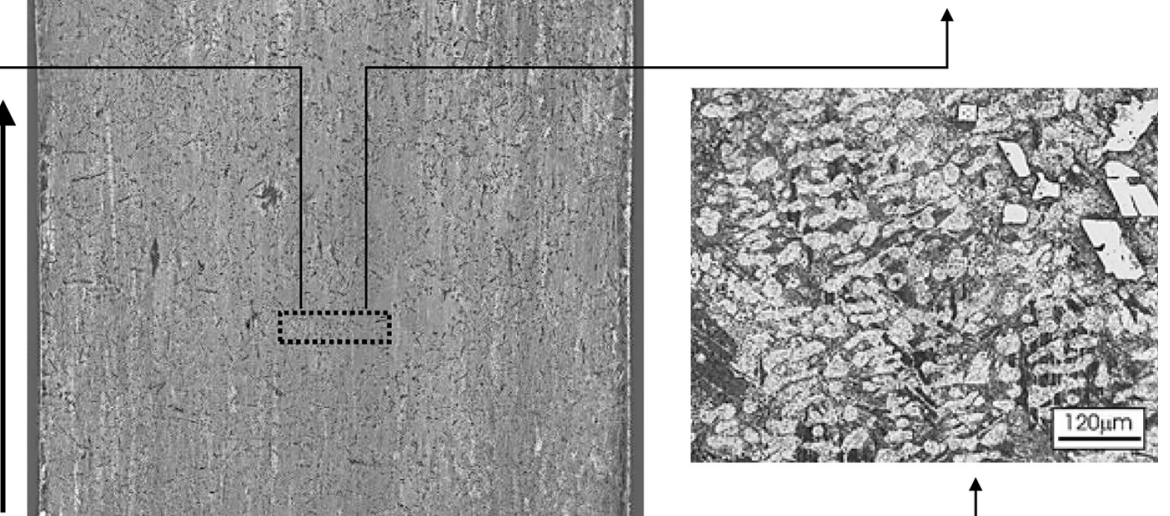
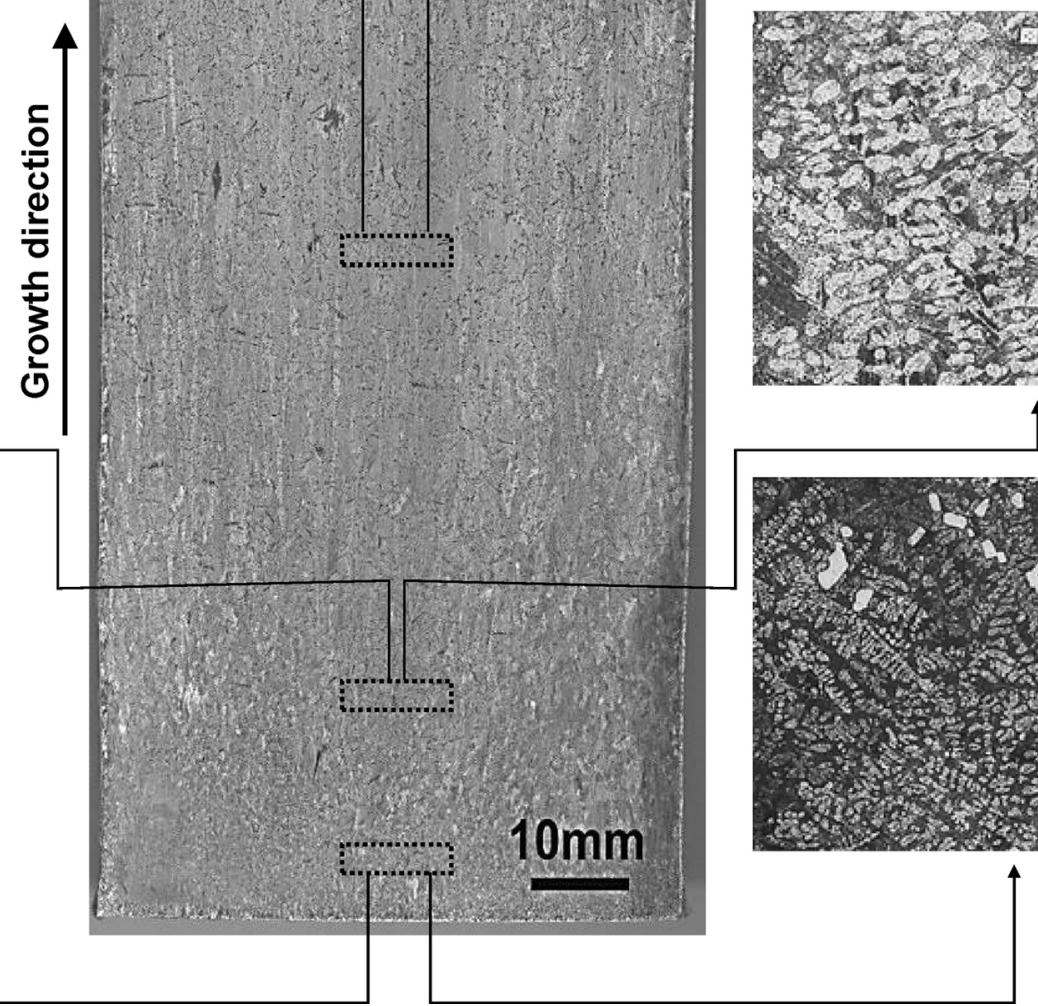

Fig. 5 Macrostructure of the ternary Sn-9 wt $\% \mathrm{Zn}-2 \mathrm{wt} \% \mathrm{Cu}$ alloy DS casting with indications of three relative positions at 5,20 and $70 \mathrm{~mm}$ from the cooled surface of the casting and their corresponding transverse and longitudinal microstructures 
(a)

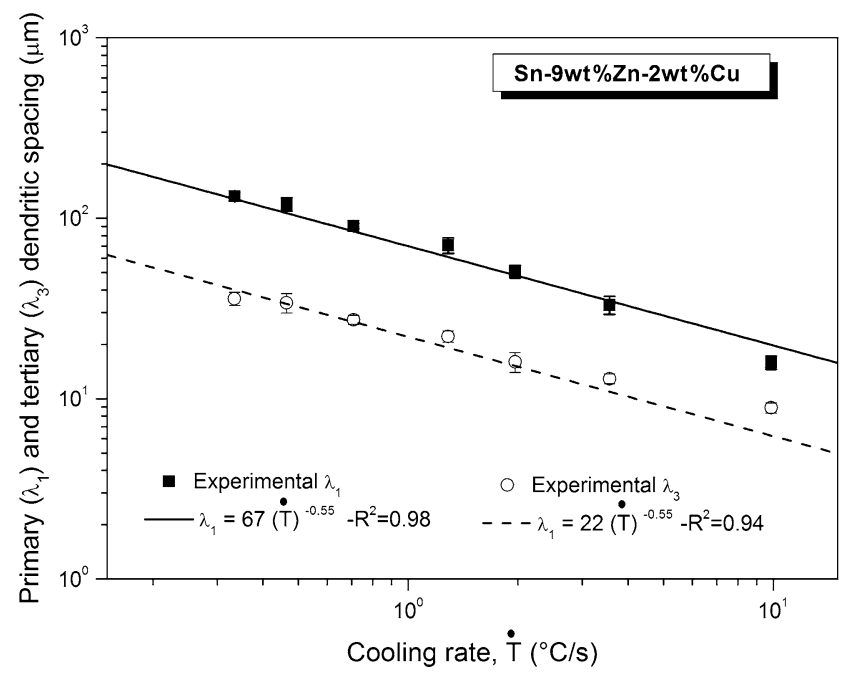

(b)

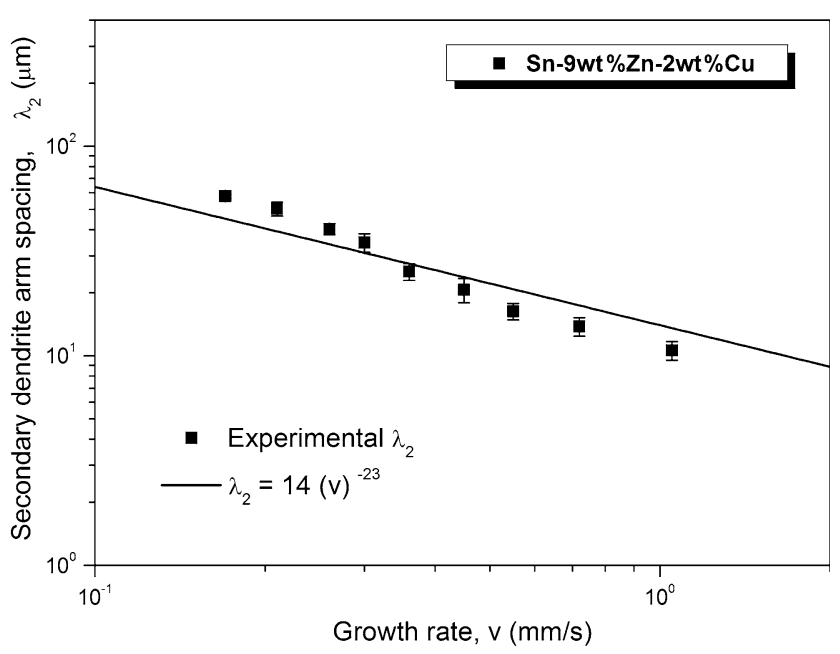

Fig. 6 a Primary/tertiary dendritic arm spacing as a function of cooling rate $(\dot{T})$, b secondary dendritic spacing as a function of growth rate (v) for the $\mathrm{Sn}-\mathrm{Zn}-\mathrm{Cu}$ alloy. $R^{2}$ is the coefficient of determination

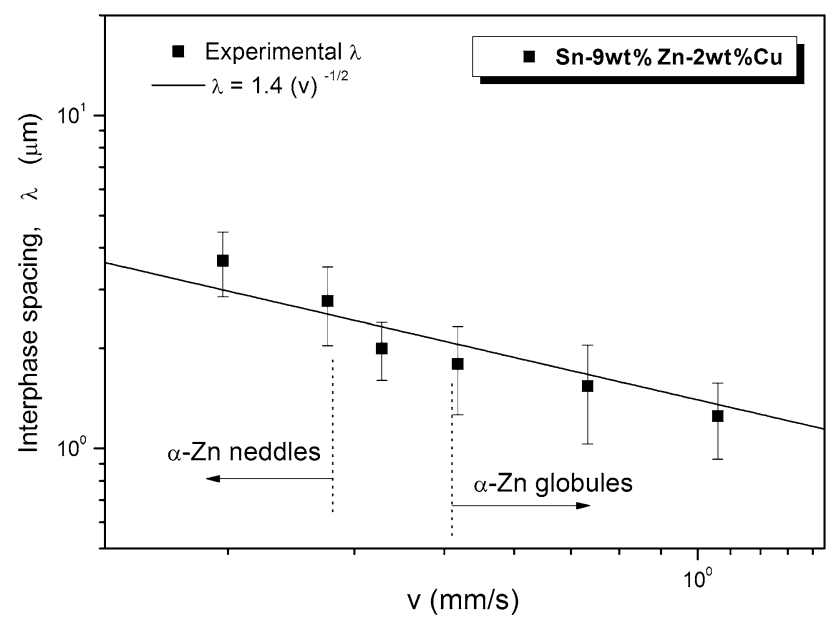

Fig. 7 Interphase spacing as a function of growth rate $(v)$ for the Sn$9 \mathrm{wt} \% \mathrm{Zn}-2 \mathrm{wt} \% \mathrm{Cu}$ alloy

the position of each thermocouple against time of passage of the liquidus isotherm by each one (see Fig. 4a). The growth rate values varied from 0.2 to $1.1 \mathrm{~mm} / \mathrm{s}$ and the $\dot{T}$ values varied from 0.2 to $12 \mathrm{~K} / \mathrm{s}$ with the experimental scatters being fitted by power functions, as indicated in Fig. 4. The cooling rate $(\dot{T})$ was determined along the length of the casting (Fig. 4c), by considering the thermal data recorded immediately after the passage of the liquidus front by each of the six thermocouples placed along the length of the casting. The thermal data around the liquidus temperature, provided by the cooling curves recorded by each thermocouple positioned along the length of the DS casting, were used to determine the coefficients of a fifthorder polynomial via the least squares method in order to generate $T=f(t)$ functions. The derivative of these functions with respect to time yielded cooling rate functions $\dot{T}=f(t)$. The experimental time corresponding to the liquidus front passing by each thermocouple was then inserted into the $\dot{T}=f(t)$ function permitting the experimental cooling rate to be determined.

The as-cast macrostructure, revealed after chemical etching of the DS $\mathrm{Sn}-\mathrm{Zn}-\mathrm{Cu}$ alloy casting, is shown in Fig. 5. Very fine columnar grains prevailed along the entire length of the casting. Furthermore, representative regions of the DS alloy casting are indicated in Fig. 5 with their corresponding microstructures. The solidification cooling rates associated with the microstructures shown in Fig. 5 from the bottom to the top of the DS casting are 9.9, 1.4 and $0.2 \mathrm{~K} / \mathrm{s}$, respectively. The micrographs shown in Fig. 5 are valuable in order to show the main phases forming this microstructure, which are $\beta$-Sn dendrites, primary $\mathrm{Cu}-\mathrm{Zn}$ phases and eutectic mixture. Additionally, it can be seen that the length scale of the microstructures increases clearly from the cooled surface of the casting toward its top. A complete dendritic array was identified with the presence not only of primary dendrite stalks but also of secondary and tertiary dendritic branches in all positions examined.

Figure 6 shows the evolutions of primary $\left(\lambda_{1}\right)$, tertiary $\left(\lambda_{3}\right)$ and secondary $\left(\lambda_{2}\right)$ dendritic arm spacings as functions of the cooling rate $(\dot{T})$ and of the growth rate $(v)$ for the $\mathrm{Sn}-$ $9 \mathrm{wt} \% \mathrm{Zn}-2 \mathrm{wt} \% \mathrm{Cu}$ alloy. The points in the graphs represent the average microstructural spacing experimentally measured along with its standard variation. Linear relationships are shown fitted to the experimental points with the aim of representing empirical power laws for the dendritic growth of the $\mathrm{Sn}-9 \mathrm{wt} \% \mathrm{Zn}-2 \mathrm{wt} \% \mathrm{Cu}$ alloy. As observed in a number of recent studies with Sn-based 
alloys $[5,14,26,27]-0.55$ and $-2 / 3$ power laws characterize the primary, tertiary and secondary dendrite arm spacings variations with cooling rate and growth rate, respectively. Such exponents were also reported as the most appropriate for representing similar experimental growth laws of $\mathrm{Sn}-\mathrm{Pb}[26,27], \mathrm{Sn}-\mathrm{Zn}$ [5], $\mathrm{Sn}-\mathrm{Ag}$ and $\mathrm{Sn}-$ Bi [14] and $\mathrm{Sn}-\mathrm{Ag}-\mathrm{Cu}$ (SAC) [28] solder alloys under transient solidification conditions. Figure 6 shows clearly that both the cooling rate and the growth rate strongly affect the microstructural spacing, with the dendritic spacings decreasing with the increase in both the cooling and growth rates.

In the studies mentioned above related to $\mathrm{Sn}-\mathrm{Zn}$ alloys [5, 14], the secondary dendritic spacings of the $\mathrm{Sn}-$ $4 \mathrm{wt} \% \mathrm{Zn}$ and $12 \mathrm{wt} \% \mathrm{Zn}$ alloys have been represented by the equations $\lambda_{2}=35(v)^{-2 / 3}$ and $\lambda_{2}=60(v)^{-2 / 3}$. Therefore, the $\lambda_{2}$ values in $\mathrm{Sn}-\mathrm{Zn}$ alloys are much larger than the present results of the ternary $\mathrm{Sn}-\mathrm{Zn}-\mathrm{Cu}$ alloy.

The average eutectic interphase spacings $(\lambda)$ with their standard deviations are shown in Fig. 7. It is known that
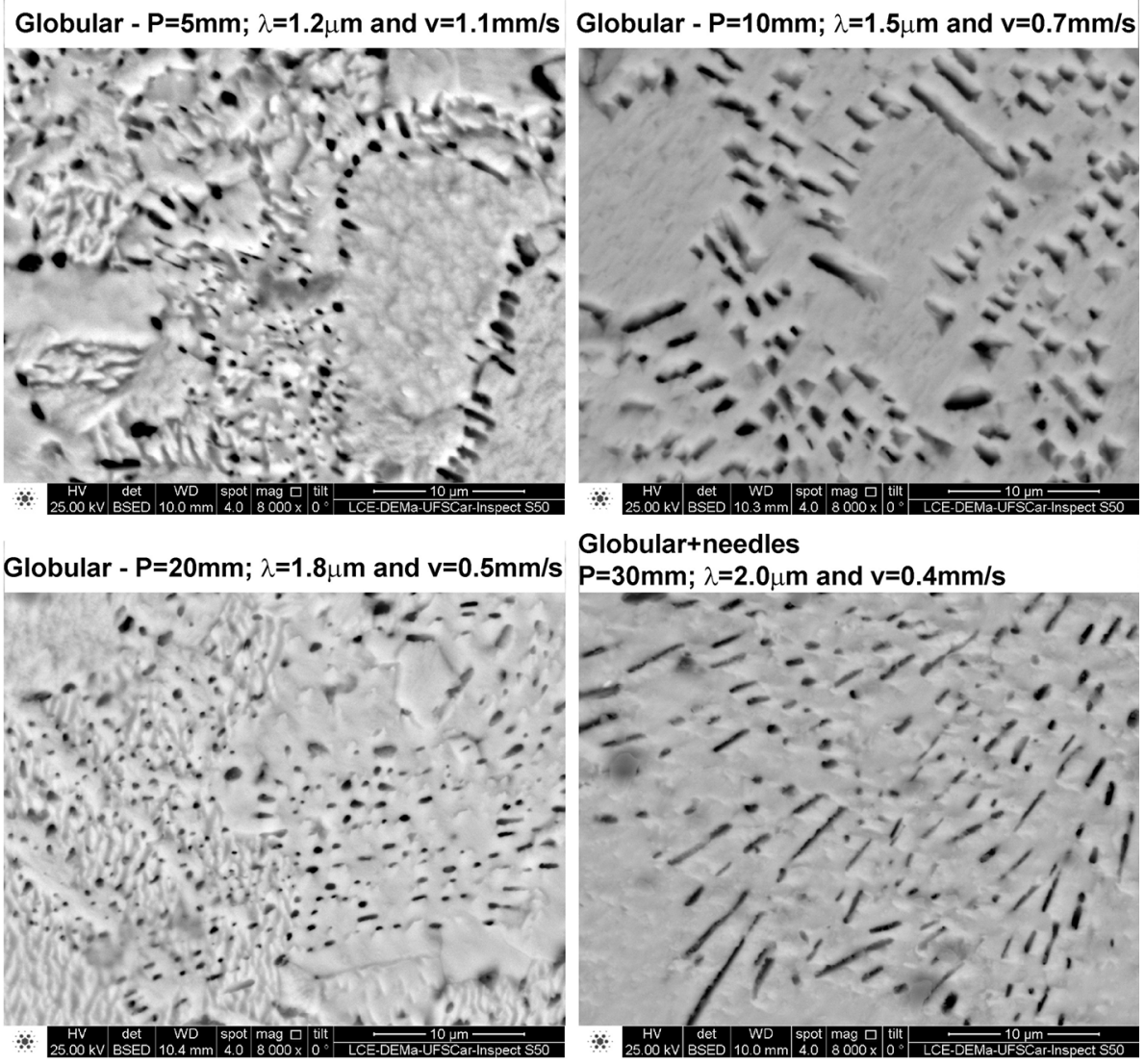

\section{Globular+needles}

$\mathrm{P}=30 \mathrm{~mm} ; \lambda=2.0 \mu \mathrm{m}$ and $\mathrm{v}=0.4 \mathrm{~mm} / \mathrm{s}$
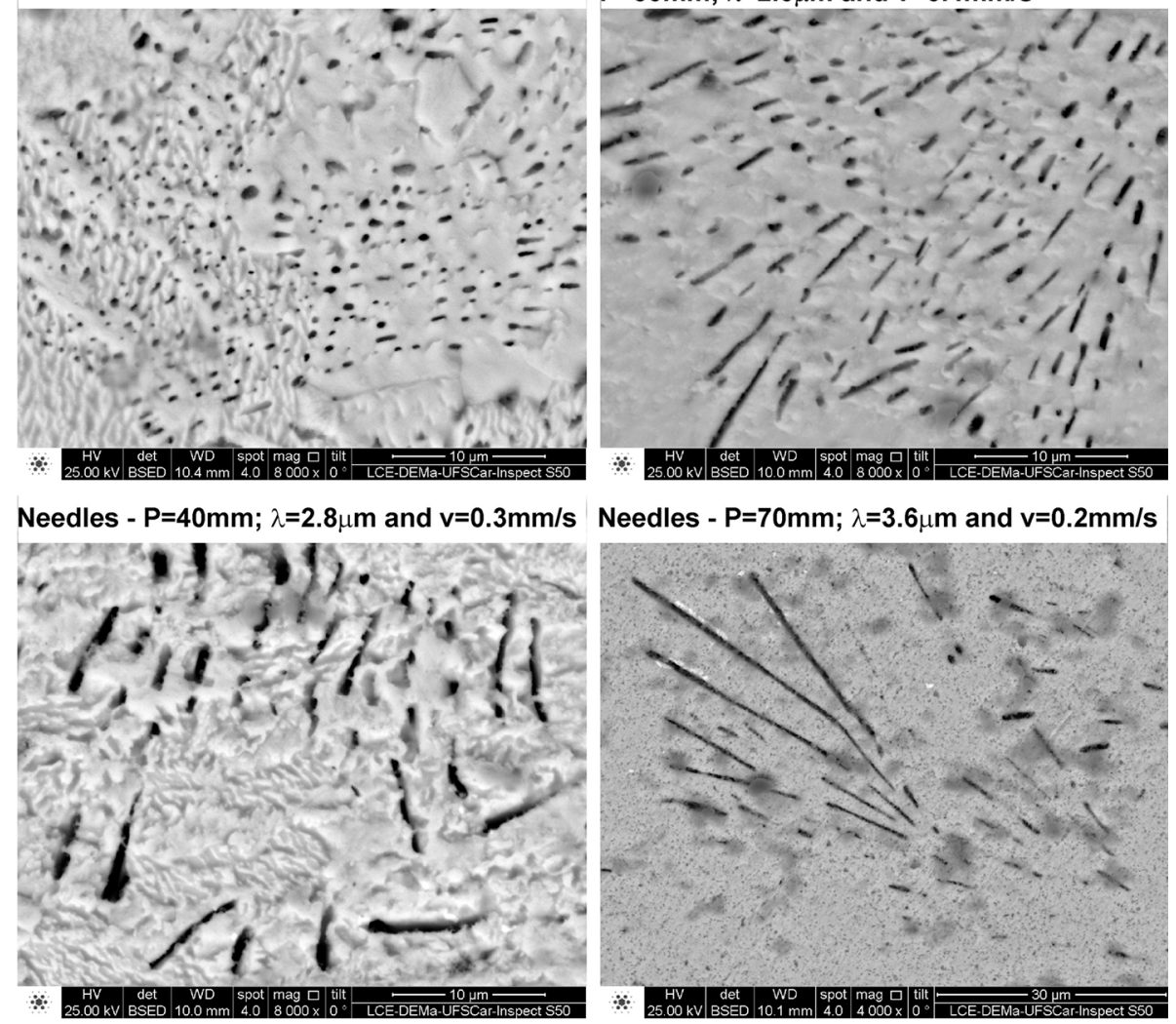

Fig. 8 SEM images of transverse sections detailing the morphological evolution of $\alpha$-Zn eutectic phase surrounded by the Sn-rich dendritic matrix in the Sn-9 wt $\% \mathrm{Zn}-2 \mathrm{wt} \% \mathrm{Cu}$ alloy. $P$ is the position from the metal/mold interface 


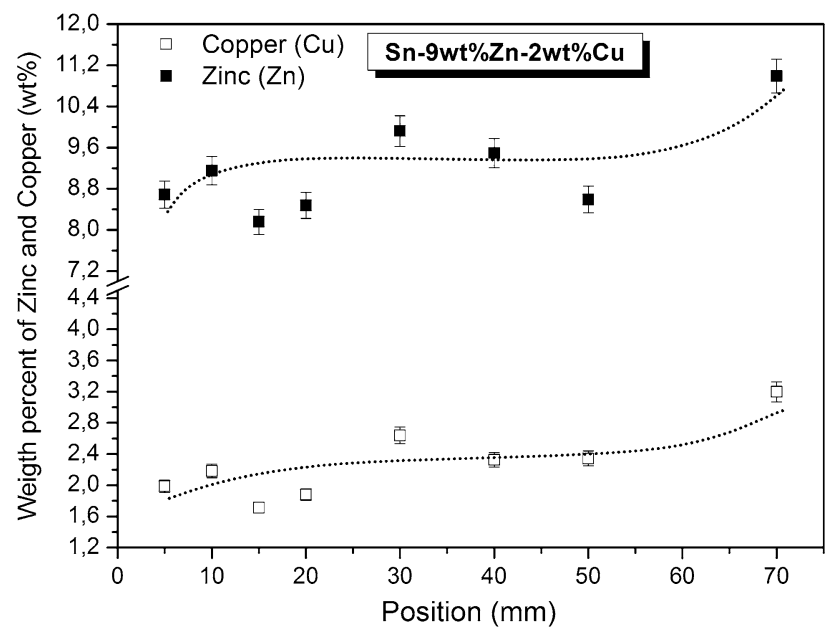

Fig. 9 Experimental $\mathrm{Zn}$ and $\mathrm{Cu}$ macrosegregation profile along the length of the DS Sn-9 wt $\% \mathrm{Zn}-2 \mathrm{wt} \% \mathrm{Cu}$ alloy DS casting

the eutectic structure has significant influence on the properties of soldered joints. However, studies emphasizing the distribution and the morphology of the eutectic phases within lead-free solder alloys remain scarce in the literature. Based on the SEM images of Fig. 8, several measurements were taken in order to determine the interphase spacings along the DS $\mathrm{Sn}-\mathrm{Zn}-\mathrm{Cu}$ alloy casting. A line in Fig. 7 represents the experimental growth law. The exponent $-1 / 2$ proposed by Jackson and Hunt for steadystate growth of lamellar eutectics [29] fairly encompasses the unsteady-state growth of the eutectic mixture considering both the $\alpha-\mathrm{Zn}$ morphologies formed, i.e., globules and needles. Kaya and coauthors [23] examined the eutectic growth of the $\mathrm{Sn}-9 \mathrm{wt} \% \mathrm{Zn}$ alloy under steadystate solidification conditions. It was likewise observed that the variation of the eutectic spacing with the growth rate was in agreement with the Jackson-Hunt eutectic theory.

The resulting eutectic microstructure of the Sn-9 wt \% $\mathrm{Zn}-2 \mathrm{wt} \% \mathrm{Cu}$ alloy, close to the bottom of the casting, is formed by a mixture of globular-like $\mathrm{Zn}$ particles embedded in a Sn-rich matrix, as can be observed in Fig. 8. However, at positions farther away from the cooled surface of the casting, needle-like particles of the $\alpha$-Zn phase start to prevail. Regions within the DS casting associated with $v>0.5$ show prevalence of globules, while the needle-like $\alpha$-Zn phase particles are restricted to $v<0.3 \mathrm{~mm} / \mathrm{s}$. These limits regarding the different eutectic morphologies of the $\mathrm{Sn}-\mathrm{Zn}-\mathrm{Cu}$ alloy apply also to the binary $\mathrm{Sn}-9 \mathrm{wt} \% \mathrm{Zn}$ alloy, as reported by Garcia et al. [14].

Figure 9 shows the experimental macrosegregation profiles of $\mathrm{Zn}$ and $\mathrm{Cu}$ along the length of the DS $\mathrm{Sn}-\mathrm{Zn}-\mathrm{Cu}$ alloy casting. The dotted lines are only representations of the evolution of segregation profiles, as can be noticed for both components examined. A positive macrosegregation (composition higher than the nominal) may be associated with regions closer to the top of the casting, which have $\mathrm{Cu}$ and $\mathrm{Zn}$ contents that are higher than that of the nominal alloy composition. Conversely, positions closer to the cooled surface of the alloy casting are associated with concentrations lower than the nominal one (negative macrosegregation). The thicker $\mathrm{Zn}$ needles associated with positions farther from the cooled surface of the casting, as shown in Fig. 8, may be not only due to the higher $\mathrm{Zn}$ content segregated on those regions but also to the slower local cooling conditions.

Figure 10 shows the elemental SEM-EDS mapping for the Sn-9 wt $\% \mathrm{Zn}-2 \mathrm{wt} \% \mathrm{Cu}$ alloy. The Sn content (in green) is higher in Sn-rich dendrites and in the eutectic mixture with a much lower intensity in other regions. $\mathrm{Zn}$

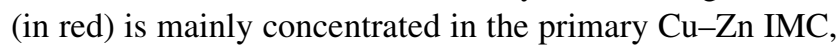
which presents different shapes depending on the position examined from the cooled surface of the DS $\mathrm{Sn}-\mathrm{Zn}-\mathrm{Cu}$ alloy casting. These shapes vary from cuboid particles at positions closer to the bottom of the casting, rod-like phases at intermediate regions and flower-like IMCs for positions closer to the top of the casting. The morphologies and sizes of these $\mathrm{Cu}-\mathrm{Zn}$ phases are out of the scope of the present study and deserve further investigation. Flowershaped and rod-shaped phases of $\mathrm{Cu}_{6} \mathrm{Sn}_{5}, \mathrm{Cu}_{5} \mathrm{Zn}_{8}$ and $\mathrm{CuZn}_{5}$ have already been reported by El-Daly and Ham$\operatorname{mad}[15]$.

These results show clearly that $\mathrm{Cu}$ (in blue) was consumed only by forming $\mathrm{Cu}-\mathrm{Zn}$ IMCs. According to these analyses, there is no evidence of $\mathrm{Cu}-\mathrm{Sn}$ intermetallic particles, despite the relatively wide range of experimental cooling rates examined, i.e., neither for fast cooling $(P=10 \mathrm{~mm} / \dot{T}=3.8 \mathrm{~K} / \mathrm{s})$ nor for slow cooling conditions $(P=70 \mathrm{~mm} / \dot{T}=0.2 \mathrm{~K} / \mathrm{s})$.

The present experimental conditions allow solidification to occur far from equilibrium conditions, which means that $\mathrm{Zn}$ and $\mathrm{Cu}$ are highly segregated at the solidification front, although $\mathrm{Zn}$ is also consumed in the eutectic reaction. Hence, the liquid immediately ahead the solid-liquid interface is enriched in $\mathrm{Cu}$ and $\mathrm{Zn}$. If $\mathrm{Cu}$ is provided in a sufficient amount, $\mathrm{Cu}_{5} \mathrm{Zn}_{8}$ is able to grown instead of $\mathrm{CuZn}_{4}$ since it has lower Gibbs free energy of formation [11].

Transient directional solidification may induce localized thermal instabilities in the vicinity of the solid-to-liquid interface. As a consequence, fluctuations in the thermal gradients in the liquid phase are expected to occur. As soon as a $\mathrm{Cu}$-based intermetallic particle starts to grow into this liquid, a non-stable solidification front is characterized and Maltese cross branches may be formed [11].

Figure 11 depicts the X-ray diffractograms obtained for the $\mathrm{Sn}-\mathrm{Zn}-\mathrm{Cu}$ solder alloy. The results of two different 


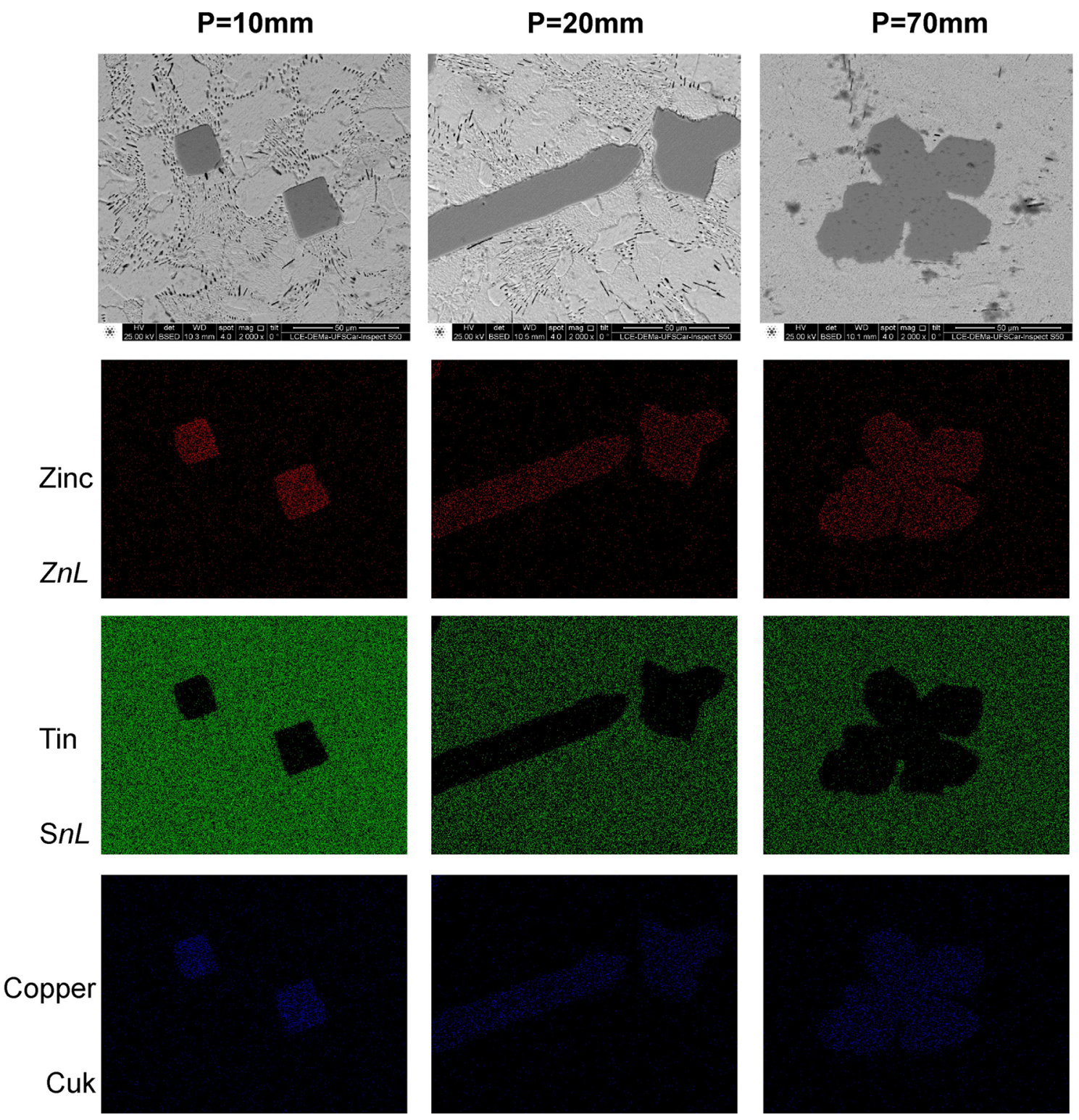

Fig. 10 Elemental SEM-EDS mappings obtained along the transverse specimen at the positions $P=10 \mathrm{~mm}, P=20 \mathrm{~mm}$ and $P=70 \mathrm{~mm}$ from the metal/mold interface of the vertically solidified $\mathrm{Sn}-9 \mathrm{wt} \% \mathrm{Zn}-2 \mathrm{wt} \% \mathrm{Cu}$ alloy casting

positions along the length of alloy casting were chosen to examine the effects of very distinct cooling rates and their impacts on the phases forming the microstructure. Figure 11 shows the presence of peaks associated with the $\mathrm{Cu}_{5} \mathrm{Zn}_{8} \mathrm{IMC}, \mathrm{Sn}$-rich and $\mathrm{Zn}$-rich phases. Other intermetallic particles could not be detected since the characteristic X-ray peaks have not been identified. This is in agreement with the elemental mappings by SEM-EDS depicted in Fig. 10.

Detailed X-ray spectra are shown in Fig. 11. Based on the intensities of the $2 \theta$ peaks ranging between $33^{\circ}$ and $54^{\circ}$, it is possible to establish that the amounts of the $\alpha-\mathrm{Zn}$ and $\mathrm{Cu}_{5} \mathrm{Zn}_{8}$ phases increase and decrease, respectively, as the cooling rate decreases from 9.9 to $0.2 \mathrm{~K} / \mathrm{s}$.
Figure 12 depicts the evolution of the hardness with the inverse of the square root of the eutectic interphase spacing for the $\mathrm{Sn}-\mathrm{Zn}-\mathrm{Cu}$ alloy examined. It can be seen that the hardness decreases with the decrease in the interphase spacing (increase in $\lambda^{-1 / 2}$ ). One would expect that samples corresponding to smaller $\lambda$ values may result in higher hardness due to a better distribution of the $\alpha-\mathrm{Zn}$ eutectic phase, since Zn has a higher hardness than Sn. However, other features of the microstructure seem to play a more significant role in the development of this property. The increase of hardness observed with increasing $\lambda$ may be associated with the corresponding decrease in the area fraction of $\mathrm{Cu}_{5} \mathrm{Zn}_{8}$ IMC, as depicted in Fig. 12. Consequently, the volume fraction of eutectic increases [16-18] 


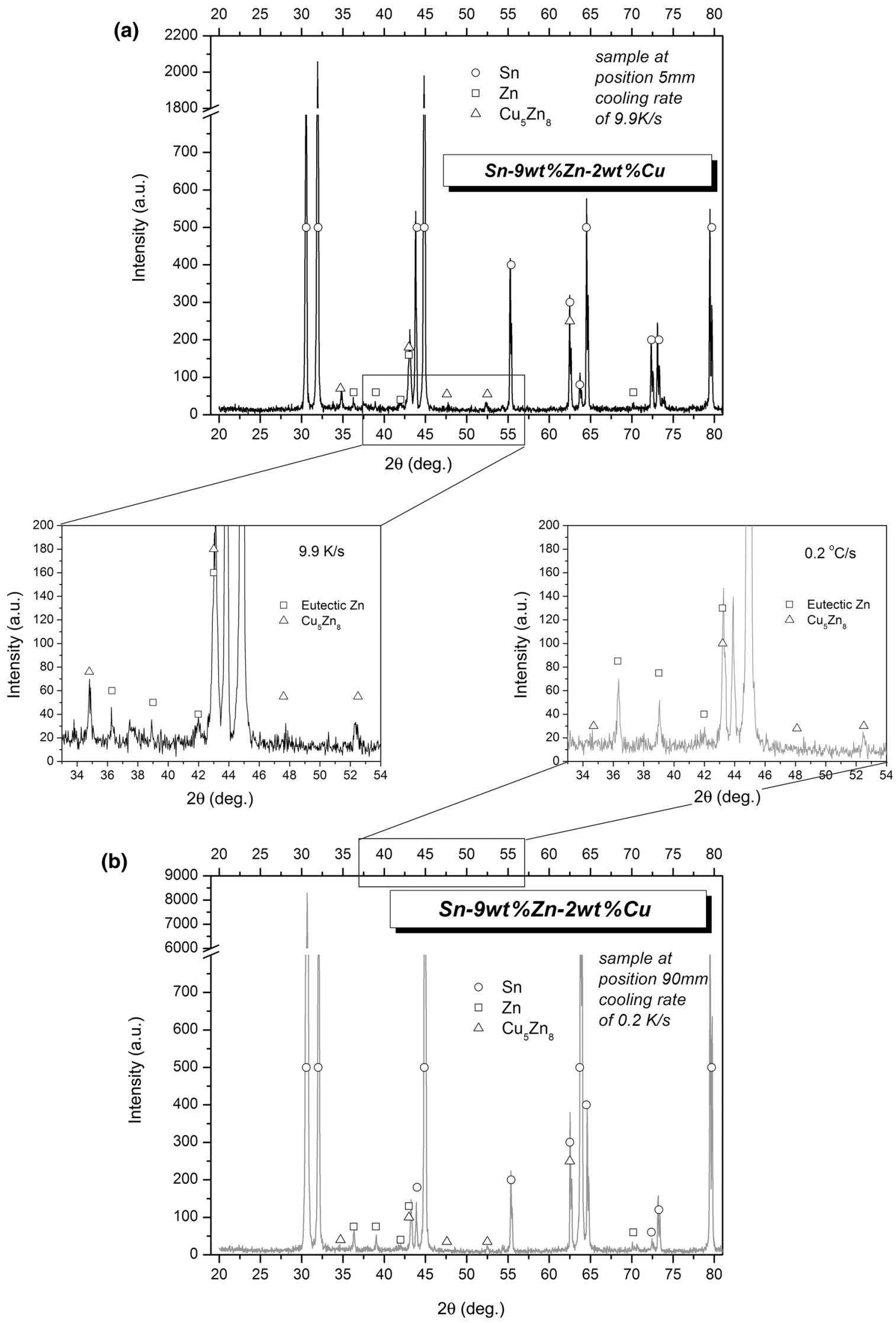

Fig. 11 XRD patterns of the Sn-9 wt\%Zn-2 wt\%Cu alloy for specific positions along the length of the DS casting: a $P=5 \mathrm{~mm}$, b $P=90 \mathrm{~mm}$ 


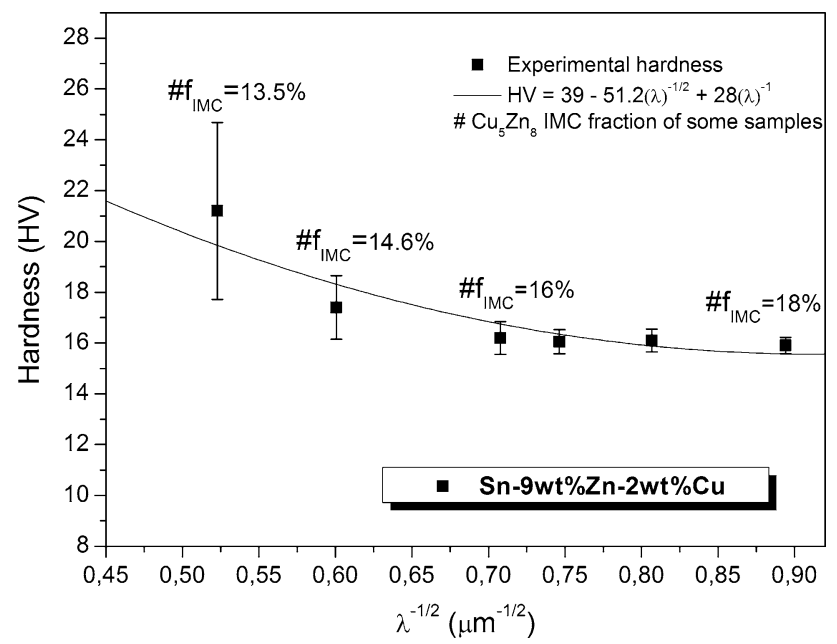

Fig. 12 Evolution of Vickers hardness as a function of the inverse of the square root of the interphase spacing for the $\mathrm{Sn}-9 \mathrm{wt} \% \mathrm{Zn}-$ $2 \mathrm{wt} \% \mathrm{Cu}$ solder alloy

because more $\mathrm{Zn}$ would be available for the eutectic reaction if less $\mathrm{Cu}_{5} \mathrm{Zn}_{8}$ IMC is formed. These average fractions of IMC were determined by counting the corresponding area fractions using an image processing software (Image J). At least 10 images were examined to yield the values inserted in Fig. 12. The evolution of the area fraction of $\mathrm{Cu}_{5} \mathrm{Zn}_{8}$ with the cooling rate is in agreement with the XRD results in Fig. 11. Higher fractions of alternated eutectic with $\beta-S n$ and $\alpha-Z n$, i.e., a reinforcing structure, combined with an increasing $\mathrm{Zn}$ content of the alloy, i.e., forming thicker $\alpha-Z n$ phase particles, can affect hardness, as shown in Fig. 12. Therefore, the interphase spacing is not the only factor affecting the hardness profile. The local solute content and the relative proportions of eutectic and of the $\alpha-\mathrm{Zn}$ and $\mathrm{Cu}_{5} \mathrm{Zn}_{8}$ phases are also able to affect the local hardness.

\section{Conclusions}

1. The as-cast microstructure of this alloy solidified under a transient solidification regime involves the presence of $\beta$-Sn dendrites, primary $\mathrm{Cu}_{5} \mathrm{Zn}_{8}$ intermetallics and a eutectic mixture of $\alpha-Z n$ and $\beta-S n$. Primary, secondary and tertiary branches along the entire length of the DS $\mathrm{Sn}-\mathrm{Zn}-\mathrm{Cu}$ alloy casting characterize the dendritic array.

2. The addition of $2.0 \mathrm{wt} \% \mathrm{Cu}$ to the binary $\mathrm{Sn}-9 \mathrm{Zn}$ alloy was shown to decrease significantly the secondary dendrite arm spacing. Further, the ternary alloy exhibited the same eutectic morphologies reported in the literature for a $\mathrm{Sn}-\mathrm{Zn}$ alloy. The same growth rate ranges, as reported for the $\mathrm{Sn}-\mathrm{Zn}$ alloy, were shown to adequately describe the morphologies of the eutectic
$\alpha-\mathrm{Zn}$ phase of the ternary alloy examined, i.e., $v>0.5 \mathrm{~mm} / \mathrm{s}$ were associated with a prevalence of globules of $\alpha$-Zn phase particles, while $v<0.3 \mathrm{~mm} / \mathrm{s}$ were associated with that of needle-like $\alpha-Z n$ phase particles.

3. The combined analyses of the SEM-EDS elemental mappings, X-ray spectra and fractions of intermetallics obtained by an image processing software showed that $\mathrm{Cu}$ was mainly consumed in the formation of the $\mathrm{Cu}_{5} \mathrm{Zn}_{8}$ intermetallic without any evidence of the presence of $\mathrm{Cu}-\mathrm{Sn}$ or of other $\mathrm{Cu}-\mathrm{Zn}$ intermetallic particles. Furthermore, the alloy $\mathrm{Zn}$ content and the evolutions of $\dot{T}$ and $v$ were found to be determinant for the growth of the $\mathrm{Cu}-\mathrm{Zn}$ IMC and its relative area fraction along the length of the DS Sn-9 wt $\% \mathrm{Zn}-$ $2 \mathrm{wt} \% \mathrm{Cu}$ casting. The decrease in the IMC area fraction with decreasing cooling rates allowed higher amounts of $\alpha$-Zn phase to be formed inside the eutectic mixture.

4. A correlation between the eutectic interphase spacing and local hardness along the length of the DS casting permitted a modified Hall-Petch-type equation relating $\mathrm{HV}$ to $\lambda$ to be proposed. The decrease in the area fraction of the $\mathrm{Cu}_{5} \mathrm{Zn}_{8}$ IMC and the consequent increase in the eutectic area fraction explained the experimentally obtained trend of $\mathrm{HV}$ along the length of the DS casting. The evolution of the $\mathrm{Zn}$ macrosegregation was also shown to have a minor effect on the hardness.

Acknowledgements The authors acknowledge the financial support provided by FAPESP (São Paulo Research Foundation, Brazil: Grants 2013/08259-3 and 2015/11863-5) and CNPq.

\section{References}

[1] M. Slupska, P. Ozga, Electroch. Acta 141, 149 (2014)

[2] X. Wang, Y. Wang, F. Wang, N. Liu, J. Wang, Acta Metall. Sin. (Engl. Lett.) 27, 1159 (2014)

[3] J.E. Spinelli, A. Garcia, J. Mater. Sci. Mater. Electron. 25, 478 (2014)

[4] F.X. Che, W.H. Zhu, E.S.W. Poh, X.W. Zhang, X.R. Zhang, J. Alloys Compd. 507, 215 (2010)

[5] W.R. Osório, L.C. Peixoto, L.R. Garcia, N. Mangelinck-Noël, A. Garcia, J. Alloys Compd. 572, 97 (2013)

[6] C. Chou, S. Chen, Acta Mater. 54, 2393 (2006)

[7] N. Zhao, H. Ma, H. Xie, L. Wang, J. Mater. Sci. Technol. 25, 410 (2009)

[8] M. Yang, X.Z. Liu, X.H. Liu, in The 11th International Conference on Electronic Packaging Technology and High Density Packaging (Xi'an, China, 2010), p. 748

[9] M. Grobelny, N. Sobczak, J. Mater. Eng. Perform. 21, 614 (2012)

[10] K. Suganuma, K. Niihara, J. Mater. Res. 13, 2859 (1998)

[11] T. Gancarz, P. Bobrowski, J. Pstruś, S. Pawlak, J. Alloys Compd. 679, 442 (2016) 
[12] K.L. Lin, C.L. Shih, J. Electron. Mater. 32, 1496 (2003)

[13] J.M. Song, G. Lan, T.S. Lui, L.H. Chen, Scr. Mater. 48, 1047 (2003)

[14] L.R. Garcia, W.R. Osório, L.C. Peixoto, A. Garcia, Mater. Charact. 61, 212 (2010)

[15] A.A. El-Daly, A.E. Hammad, Mater. Sci. Eng. A 527, 5212 (2010)

[16] M. Rahman, A. Sharif, M. Ahmed, in Proceedings of the International Conference on Mechanical Engineering (Dhaka, Bangladesh, 2009), p. 26

[17] J. Lee, K. Kim, M. Inoue, J. Jiang, K. Suganuma, J. Alloys Compd. 454, 310 (2008)

[18] S. Liu, S. Xue, P. Xue, D. Luo, J. Mater. Sci. Mater. Electron. 26, 4389 (2015)

[19] J.E. Spinelli, A. Garcia, Mater. Sci. Eng. A 568, 195 (2013)

[20] B.L. Silva, N. Cheung, A. Garcia, J.E. Spinelli, J. Electron. Mater. 42, 179 (2013)
[21] W.R. Osório, D.R. Leiva, L.C. Peixoto, L.R. Garcia, A. Garcia, J. Alloys Compd. 562, 194 (2013)

[22] U. Böyük, N. Maraşli, Mater. Chem. Phys. 119, 442 (2010)

[23] H. Kaya, E. Çadırlı, M. Gunduz, J. Mater. Eng. Perform. 12, 456 (2003)

[24] M. Gunduz, E. Çadirli, Mater. Sci. Eng., A 327, 167 (2002)

[25] S. Farahany, A. Ourdjini, Mater. Manufact. Proc. 28, 657 (2013)

[26] F. Sá, O.L. Rocha, C.A. Siqueira, A. Garcia, Mater. Sci. Eng. A 373, 131 (2004)

[27] O.L. Rocha, C.A. Siqueira, A. Garcia, Mater. Sci. Eng. A 361, 111 (2003)

[28] J.E. Spinelli, B.L. Silva, A. Garcia, J. Electron. Mater. 43, 1347 (2014)

[29] K.A. Jackson, J.D. Hunt, T. Metall, Soc. AIME 236, 1129 (1966) 